\title{
Mapping Intermodal Transportation Through Bibliometrics
}

\author{
Sanjeev Kadam, Prabir Kumar Bandyopadhyay
}

\begin{abstract}
Almost every business operation necessitates the use of intermodal transportation at some stage in the supply chain. This study is aimed to map reputation and interconnectedness among existing literature in the area of intermodal transportation. For this purpose, firstly, bibliometric data of 1758 documents are retrieved using keyword 'intermodal transportation' from the Scopus database. Data has been processed to build bibliometrics between publications, authors, co-authors, sources, citations, affiliation, country of origin. Secondly, the reputation of literature in intermodal transportation being surveyed using citation and network analysis. Finally, considering citations literature of highly cited was reviewed. Opensource software such as table2net, sciencescape, gephi, has been used to build network diagrams. The outcome of this research would lay the groundwork to pursue detailed study in the area of intermodal transportation. Some of the findings are; researchers from the US and Europe are leading in publishing researches in this field; 'intermodal transportation' and 'intermodal transport' are popular keywords among the research fraternity; 'engineering' and 'social sciences' are preferred subject areas; mostly transportation and operations research journals are preferred journals; and increasing trends have been observed in intermodal transportation research since 2005.
\end{abstract}

Keyword-Bibliometrics, citation, intermodal transportation, literature review, network diagram.

\section{INTRODUCTION}

Intermodal transportation is a process of transportation of passenger or goods from origin to destination using a combination of different transportation modes. Nowadays, almost every business operation necessitates the use of intermodal transportation at some stage in the supply chain. Supply and demand from international suppliers and customers are on the rise due to effective and efficient intermodal transportation in the supply chain. Transportation infrastructure development such as roads, ports, airports have brought revolution in logistics operational services across the world. Designing a highly responsive and highly efficient supply chain has become extremely important in freight transportation. World trade volume in 2017 increased by $3.6 \%$, which is twice the growth rate in 2016. World container traffic (measured in TEU's) and air freight tonne$\mathrm{km}$ increased by $4.8 \%$ and $9.0 \%$ respectively in 2017

Revised Manuscript Received on September 10, 2019.

Sanjeev Kadam, SCRI, Symbiosis International (Deemed University) ,Pune, Maharstra, India. Amity business school, Amity University, Munmbai, Maharastra, India.

(Email: sckadam@mum.amiy.edu,sk.ymtcom@gmail.com)

Prabir Kumar Bandyopadhyay, Symbiosis Institue of Business management ,Pune, Maharstra, India.

(Email:prabirpadhyay@simpune.com)
No doubt, today's logistics operations intermodal transportation observes many benefits over unimodal transportation. Generally, intermodal transportation utilises any one or more channels for transportation form origin to destination as shown in Fig. 1.

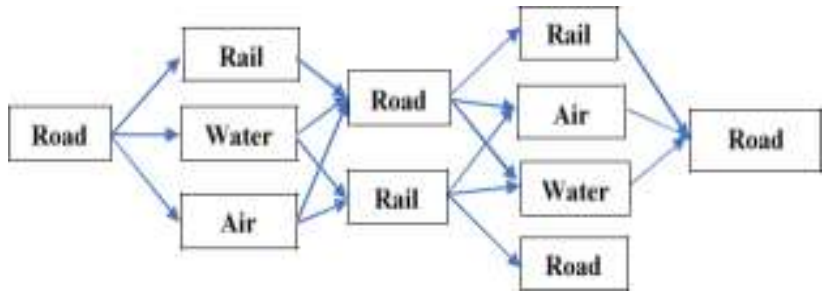

Fig. 1. Typical model of intermodal transportation

\section{A. $\quad$ Objectives of the study:}

The study is aimed:

1. To explore existence of academic research in intermodal transportation

2. To conduct citation and network analysis for intermodal transportation literature

3. To conduct systematic literature review of highly cited publications in intermodal transportation.

4. To pinpoint the scope of further research

B. Methodology of the study:

Firstly, 1758 publications were retrieved using 'intermodal transportation' as a basic keyword search in Scopus database as shown in Fig. 2.

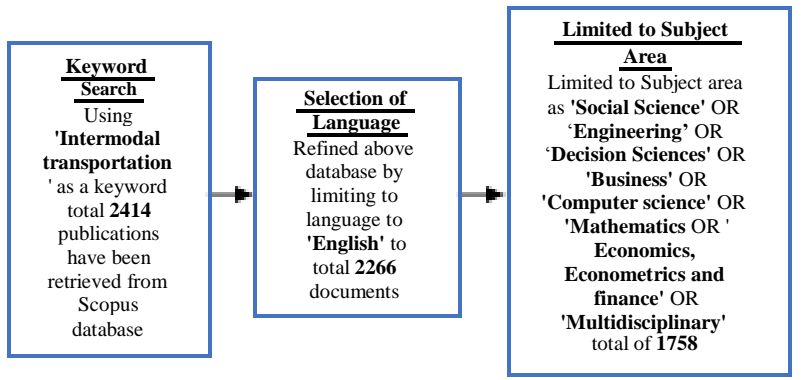

Fig. 2 Keyword research methodology 
Secondly, this retrieved and refined database further analysed by using metrics such as geographical analysis, bibliometric analysis, citation analysis and network analysis

Finally, a systematic literature review will be conducted using leading publications from the leading journals to

understand the strength of academic research in the intermodal transportation area.

\section{MAPPING INTERMODAL TRANSPORTATION.}

In this section geographic, bibliometrics, citations and network analysis has been discussed in detail.

\section{A. Geographical analysis:}

Table 1 shows the top 10 countries in intermodal transportation research. Researchers from the United States has more interest in intermodal transportation followed by China and Italy.

Table 1 Top 10 Countries in the area of

\begin{tabular}{lclc}
\hline Country & \multicolumn{2}{c}{ intermodal transportation research } \\
\hline $\begin{array}{c}\text { Number of } \\
\text { Publications } \\
\text { associated }\end{array}$ & \multicolumn{1}{c}{ Country } & $\begin{array}{c}\text { Number of } \\
\text { Publications } \\
\text { associated }\end{array}$ \\
\hline United States & 522 & Belgium & 68 \\
\hline China & 129 & United Kingdom & 67 \\
\hline Italy & 118 & Canada & 58 \\
\hline Germany & 101 & Spain & 51 \\
\hline Netherlands & 78 & France & 49 \\
\hline
\end{tabular}

Fig. 3 is drawn using gpsvisualizer.com which demonstrates geographical locations of publications and researchers associated with intermodal transportation. The size of the circle indicates that the United States has the highest number of researchers and publications in the area of intermodal transportation

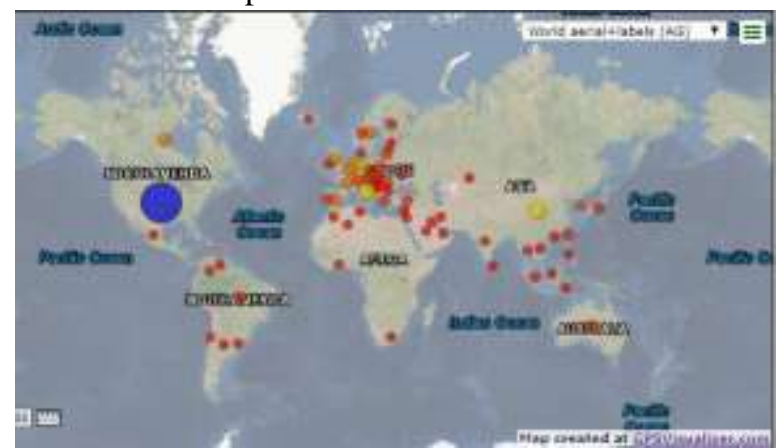

Fig. 3. Geographical locations of publications and researchers associated with intermodal transportation

C. Bibliometric analysis:

\begin{tabular}{lclc}
\hline Document Type & $\begin{array}{c}\text { Number of } \\
\text { publications }\end{array}$ & $\begin{array}{c}\text { Document } \\
\text { Type }\end{array}$ & $\begin{array}{c}\text { Number of } \\
\text { publications }\end{array}$ \\
\hline Article & 960 & Article in Press & 8 \\
\hline Conference Paper & 706 & Note & 4 \\
\hline Review & 43 & Short Survey & 3 \\
\hline Conference Review & 33 & Erratum & 1
\end{tabular}

Fig. 4 reveals that in 1995 there were 76 publications which has fallen to 40 in 2005 and since then yearly publications in intermodal transportation is on rise as indicated by trendline.

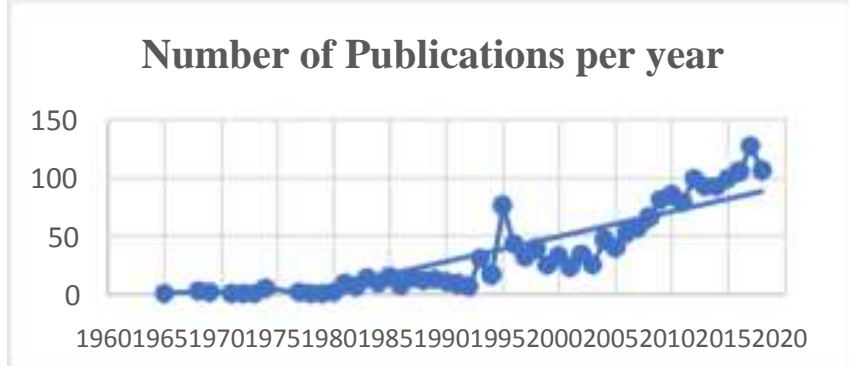

Fig. 4. Yearly publication analysis in intermodal transportation

Table 3. Top 10 author statistics in intermodal transportation

\begin{tabular}{lclc}
\hline \multicolumn{1}{c}{ Author } & $\begin{array}{c}\text { Number of } \\
\text { Publications }\end{array}$ & \multicolumn{1}{c}{ Author } & $\begin{array}{c}\text { Number of } \\
\text { Publications }\end{array}$ \\
\hline Caris, A. & 22 & Negenborn, R.R. & 13 \\
\hline Macharis, C. & 19 & Ukovich, W. & 13 \\
\hline Janssens, G.K. & 17 & Di Febbraro, A. & 12 \\
\hline Anon & 16 & Fanti, M.P. & 12 \\
\hline Dotoli, M. & 16 & Sacone, S. & 11 \\
\hline
\end{tabular}

Table 4. Top 10 keywords statistics in intermodal transportation

\begin{tabular}{lclc}
\hline \multicolumn{1}{c}{ Keywords } & $\begin{array}{l}\text { Number of } \\
\text { Associated } \\
\text { Publications }\end{array}$ & \multicolumn{1}{c}{ Keywords } & $\begin{array}{c}\text { Number of } \\
\text { Associated } \\
\text { Publications }\end{array}$ \\
\hline $\begin{array}{l}\text { Intermodal } \\
\text { Transportation }\end{array}$ & 446 & $\begin{array}{l}\text { Freight } \\
\text { Transport }\end{array}$ & 158 \\
\hline $\begin{array}{l}\text { Freight } \\
\text { Transportation }\end{array}$ & 336 & $\begin{array}{l}\text { Transportation } \\
\text { Planning }\end{array}$ & 138 \\
\hline Transportation & 322 & Containers & 131 \\
\hline $\begin{array}{l}\text { Intermodal } \\
\text { Transport }\end{array}$ & 266 & Logistics & 121 \\
\hline Railroad & 195 & Optimization & 119 \\
Transportation & & &
\end{tabular}

Table 5. Top 10 subject areas statistics in intermodal transportation

\begin{tabular}{|c|c|c|c|}
\hline Subject Area & $\begin{array}{c}\text { Number of } \\
\text { Associated } \\
\text { Publications }\end{array}$ & Subject Area & $\begin{array}{c}\text { Number of } \\
\text { Associated } \\
\text { Publications }\end{array}$ \\
\hline Engineering & 1064 & $\begin{array}{l}\text { Environmental } \\
\text { Science }\end{array}$ & 176 \\
\hline Social Sciences & 817 & Mathematics & 125 \\
\hline $\begin{array}{l}\text { Computer } \\
\text { Science }\end{array}$ & 360 & $\begin{array}{l}\text { Economics, } \\
\text { Econometrics and } \\
\text { Finance }\end{array}$ & 60 \\
\hline $\begin{array}{l}\text { Decision } \\
\text { Sciences }\end{array}$ & 214 & Energy & 37 \\
\hline $\begin{array}{l}\text { Business, } \\
\text { Management } \\
\text { and Accounting }\end{array}$ & 197 & $\begin{array}{l}\text { Earth and } \\
\text { Planetary } \\
\text { Sciences }\end{array}$ & 28 \\
\hline Engineering & 1064 & $\begin{array}{l}\text { Environmental } \\
\text { Science }\end{array}$ & 176 \\
\hline
\end{tabular}


Table 6 Top 10 source titles statistics in intermodal transportation

\begin{tabular}{|c|c|c|c|}
\hline Source Title & $\begin{array}{c}\text { Number of } \\
\text { Associated } \\
\text { Publications }\end{array}$ & Source Title & $\begin{array}{c}\text { Number of } \\
\text { Associated } \\
\text { Publications }\end{array}$ \\
\hline $\begin{array}{l}\text { Transportation } \\
\text { Research } \\
\text { Record }\end{array}$ & 55 & $\begin{array}{l}\text { Transportation } \\
\text { Congress } \\
\text { Proceedings }\end{array}$ & 29 \\
\hline $\begin{array}{l}\text { Transportation } \\
\text { Research Part } \\
\text { E Logistics } \\
\text { and } \\
\text { Transportation } \\
\text { Review }\end{array}$ & 48 & $\begin{array}{l}\text { Transportation } \\
\text { Research Part A } \\
\text { Policy and } \\
\text { Practice }\end{array}$ & 24 \\
\hline $\begin{array}{l}\text { Journal of } \\
\text { Transport } \\
\text { Geography }\end{array}$ & 38 & $\begin{array}{l}\text { Transportation } \\
\text { Planning and } \\
\text { Technology }\end{array}$ & 22 \\
\hline $\begin{array}{l}\text { Transportation } \\
\text { Quarterly }\end{array}$ & 35 & $\begin{array}{l}\text { European } \\
\text { Journal of } \\
\text { Operational } \\
\text { Research }\end{array}$ & 21 \\
\hline $\begin{array}{l}\text { Railway } \\
\text { Gazette } \\
\text { International }\end{array}$ & 30 & $\begin{array}{l}\text { Transport Means } \\
\text { Proceedings of } \\
\text { The International } \\
\text { Conference }\end{array}$ & 20 \\
\hline
\end{tabular}

Though USA tops the list of publications in intermodal transportation, the affiliation statistics shown in table 7 reveals that, European universities are leading in affiliating researches in intermodal transportation.

Table 7 Top 10 affiliation statistics in intermodal transportation

\begin{tabular}{lccc}
\hline Affiliation & $\begin{array}{c}\text { Number of } \\
\text { Associated } \\
\text { Publications }\end{array}$ & Affiliation & $\begin{array}{c}\text { Number of } \\
\text { Associated } \\
\text { Publications }\end{array}$ \\
\hline $\begin{array}{l}\text { Delft } \\
\text { University of }\end{array}$ & 53 & $\begin{array}{l}\text { Vrije Universiteit } \\
\text { Brussel, Belgium }\end{array}$ & 20 \\
\hline $\begin{array}{l}\text { University of } \\
\text { Genoa, Italy }\end{array}$ & 31 & $\begin{array}{l}\text { University of } \\
\text { Zilina, Slovakia }\end{array}$ & 18 \\
\hline $\begin{array}{l}\text { Vilnius } \\
\text { Gediminas } \\
\text { Technical } \\
\text { University, }\end{array}$ & 26 & Mississippi State & 17 \\
Lithuania & & University, USA & \\
\hline
\end{tabular}

\begin{tabular}{llll}
\hline $\begin{array}{l}\text { Polytechnic } \\
\text { University of }\end{array}$ & 23 & $\begin{array}{l}\text { RWTH Aachen } \\
\text { University, } \\
\text { Bari, Italy }\end{array}$ & 17 \\
\hline University of & 21 & $\begin{array}{l}\text { University of } \\
\text { Trieste, Italy }\end{array}$ & 15 \\
$\begin{array}{l}\text { Hasselt, } \\
\text { Belgium }\end{array}$ & & & \\
\hline
\end{tabular}

\section{Citation analysis}

Citation is a measure to determine the qualitative significance of a publication in the academic fraternity. Citation analysis aims to determine the 'popularity' of a publication by counting the number of times a publication cited by other publications (Ding and Cronin, 2011)[3]. Bornmann and Daniel (2008) analyzed that citations are "complex, multidimensional and not a unidimensional phenomenon"[4]. However, Hong and Kaur (2008) stated that citations might not be useful for judging the research quality[5].

Out of 1758 retrieved publications in intermodal transportation, only 992 have been cited at least once till the date of retrieval. Table 8 shows total citations received by the publications. It is evident from the increasing trend of citations that researches in intermodal transportations are becoming popular year by year

Table 8 Yearly citations analysis for publications in intermodal transportation

\begin{tabular}{lc}
\hline Year & Number of Citations \\
\hline$<2009$ & 1729 \\
\hline 2009 & 456 \\
\hline 2010 & 590 \\
\hline 2011 & 752 \\
\hline 2012 & 971 \\
\hline 2013 & 1100 \\
\hline 2014 & 1294 \\
\hline 2015 & 1563 \\
\hline 2016 & 1777 \\
\hline 2017 & 2028 \\
\hline 2018 & 2371 \\
\hline$>2018$ & 159 \\
\hline Total & $\mathbf{1 4 7 9 0}$ \\
\hline
\end{tabular}

Table 9 shows list of top 10 cited publications in the area of intermodal transportation

Table 9 Top 10 publications in intermodal transportation based on citations received

\begin{tabular}{|c|c|c|c|c|}
\hline Year & Publications Title & Authors & Source Title & Number of Citations \\
\hline 2004 & $\begin{array}{l}\text { Opportunities for OR in intermodal } \\
\text { freight transport research: A review }\end{array}$ & $\begin{array}{ll}\text { Macharis } & \text { C., } \\
\text { Bontekoning Y.M. } & \end{array}$ & $\begin{array}{l}\text { European Journal } \\
\text { Operational Research } \\
\end{array}$ & 309 \\
\hline 2004 & $\begin{array}{l}\text { Is a new applied transportation } \\
\text { research field emerging? - A review } \\
\text { of intermodal rail-truck freight } \\
\text { transport literature }\end{array}$ & $\begin{array}{l}\text { Bontekoning Y.M., } \\
\text { Macharis C., Trip J.J. }\end{array}$ & $\begin{array}{l}\text { Transportation Research Part } \\
\text { A: Policy and Practice }\end{array}$ & 253 \\
\hline 2003 & $\begin{array}{l}\text { Storage space allocation in } \\
\text { container terminals }\end{array}$ & $\begin{array}{l}\text { Zhang C., Liu J., Wan } \\
\text { Y.-W., Murty K.G., } \\
\text { Linn R.J. }\end{array}$ & $\begin{array}{l}\text { Transportation Research Part B: } \\
\text { Methodological }\end{array}$ & 240 \\
\hline 2007 & $\begin{array}{l}\text { Modelling the full costs of an } \\
\text { intermodal and } \\
\text { transport network }\end{array}$ & Janic M. & $\begin{array}{l}\text { Transportation Research Part } \\
\text { D: Transport and Environment }\end{array}$ & 206 \\
\hline 2014 & $\begin{array}{l}\text { Multimodal freight transportation } \\
\text { planning: A literature review }\end{array}$ & $\begin{array}{l}\text { Steadieseifi M., Dellaert } \\
\text { N.P., Nuijten W., Van } \\
\text { Woensel T., Raoufi R. }\end{array}$ & $\begin{array}{l}\text { European Journal } \\
\text { Operational Research }\end{array}$ & 173 \\
\hline 1981 & $\begin{array}{l}\text { Containerization and the load center } \\
\text { concept. }\end{array}$ & Hayut Y. & Economic Geography & 167 \\
\hline
\end{tabular}




\begin{tabular}{|c|c|c|c|c|}
\hline 2004 & $\begin{array}{l}\text { Modelling a rail/road } \\
\text { transportation system }\end{array}$ & $\begin{array}{l}\text { Arnold P., Peeters D., } \\
\text { Thomas I. }\end{array}$ & $\begin{array}{l}\text { Transportation Research Part E: } \\
\text { Logistics and Transportation } \\
\text { Review }\end{array}$ & 152 \\
\hline 2002 & $\begin{array}{l}\text { Empty container management for } \\
\text { intermodal transportation networks }\end{array}$ & $\begin{array}{l}\text { Choong S.T.,Cole } \\
\text { M.H., Kutanoglu E. }\end{array}$ & $\begin{array}{l}\text { Transportation Research Part E: } \\
\text { Logistics and Transportation } \\
\text { Review }\end{array}$ & 143 \\
\hline 2005 & $\begin{array}{l}\text { Optimal location of intermodal } \\
\text { freight hubs }\end{array}$ & Racunica I., Wynter L. & $\begin{array}{l}\text { Transportation Research Part B: } \\
\text { Methodological }\end{array}$ & 135 \\
\hline 2000 & $\begin{array}{l}\text { Intermodal and international freight } \\
\text { network modeling }\end{array}$ & $\begin{array}{l}\text { Southworth F., Peterson } \\
\text { B.E. }\end{array}$ & $\begin{array}{l}\text { Transportation Research Part C: } \\
\text { Emerging Technologies }\end{array}$ & 133 \\
\hline
\end{tabular}

Table 10 is a list of top 10 source titles in the area of with 48 publications which have been cited 1441 times till intermodal transportation. 'Transportation Research Part E: date of retrieval of the data used for this research.

Logistics and Transportation Review' is a topmost journal

Table 10 Top 10 journals in intermodal transportation based on citations received

\begin{tabular}{|c|c|c|c|c|c|c|c|c|c|c|c|c|c|c|}
\hline Journal Title & 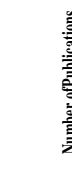 & $\underset{\hat{\tilde{O}}}{\mathrm{~V}}$ & ڤิ̀े & 을 & $\overline{\bar{乛}}$ & בับ & 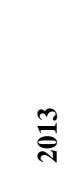 & 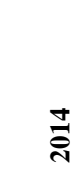 & 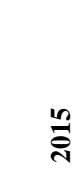 & స้ำ & 독 & $\stackrel{\infty}{\frac{\pi}{\pi}}$ & $\stackrel{\infty}{\stackrel{\lambda}{્}}$ & $\stackrel{\pi}{0}$ \\
\hline $\begin{array}{l}\text { Transportation Research } \\
\text { Part E: Logistics and } \\
\text { Transportation Review }\end{array}$ & 48 & 119 & 49 & 69 & 82 & 102 & 136 & 117 & 164 & 168 & 189 & 229 & 17 & 1441 \\
\hline $\begin{array}{l}\text { European Journal of } \\
\text { Operational Research }\end{array}$ & 21 & 107 & 65 & 68 & 79 & 110 & 97 & 115 & 151 & 146 & 172 & 188 & 8 & 1306 \\
\hline $\begin{array}{l}\text { Transportation Research } \\
\text { Part A: Policy and Practice }\end{array}$ & 25 & 102 & 42 & 48 & 55 & 75 & 77 & 99 & 97 & 110 & 124 & 115 & 7 & 951 \\
\hline $\begin{array}{l}\text { Transportation Research } \\
\text { Part B: Methodological }\end{array}$ & 20 & 125 & 43 & 45 & 46 & 67 & 77 & 81 & 85 & 83 & 99 & 136 & 9 & 896 \\
\hline $\begin{array}{l}\text { Journal of Transport } \\
\text { Geography }\end{array}$ & 38 & 43 & 17 & 19 & 40 & 51 & 69 & 86 & 100 & 138 & 136 & 171 & 17 & 887 \\
\hline $\begin{array}{l}\text { Transportation Planning } \\
\text { and Technology }\end{array}$ & 22 & 40 & 10 & 24 & 44 & 53 & 36 & 62 & 59 & 61 & 64 & 47 & 3 & 503 \\
\hline $\begin{array}{l}\text { Transportation Research } \\
\text { Part D: Transport and } \\
\text { Environment }\end{array}$ & 19 & 42 & 16 & 20 & 29 & 39 & 32 & 38 & 57 & 66 & 74 & 84 & 2 & 499 \\
\hline Transportation Science & 9 & 119 & 12 & 19 & 17 & 20 & 32 & 45 & 45 & 35 & 42 & 52 & 4 & 442 \\
\hline Transport Policy & 19 & 10 & 8 & 20 & 13 & 11 & 25 & 45 & 58 & 86 & 61 & 88 & 5 & 430 \\
\hline $\begin{array}{l}\text { Computers and Operations } \\
\text { Research }\end{array}$ & 7 & 13 & 6 & 11 & 25 & 28 & 37 & 42 & 48 & 51 & 58 & 74 & 4 & 397 \\
\hline
\end{tabular}

\section{Network analysis:}

Network analysis is a graphical representation used to build the relationship between different statistical parameters. Open source software such as 'ScienceScape' and 'Table2Net' is used to build a basic network and in turn, is used as basic input for 'gephi'. With the help of 'gephi' we can visualise and explore bibliometrics through graphs and networks. Fig. 5 represents an association between main authors, main keywords and main journals 


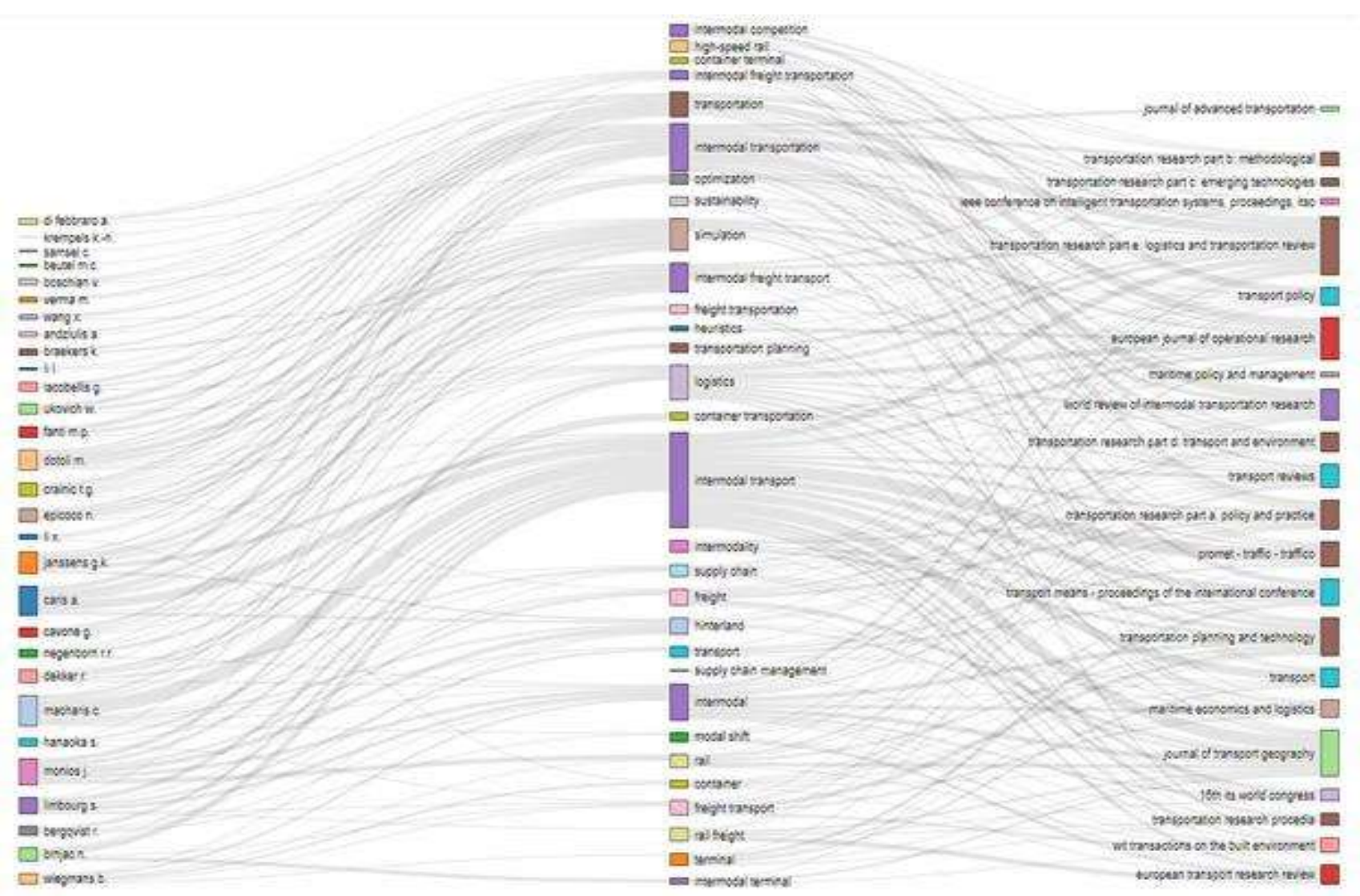

Main Authors

Main Keywords

Main Journals

Fig. 5. Network Association of main authors, main keywords and main journals

Fig. 6 is created using authors and author keywords, coappearing in the same papers with the following configuration:

Nodes: 3824 Edges: 11042; Filtering Mode: Remove nodes < 3 links; Disconnected nodes removed: 2358

Further, it is filtered manually setting degree filter to 15-323. It builds a network diagram shown in Fig. 6 with
160 nodes and 413 edges. It is evident that 'Macharis, C', 'Caris, A 'and 'Janssens, G.K' are the prominent authors connected with the top keywords 'intermodal transportation' and 'intermodal transport' as shown in Fig.

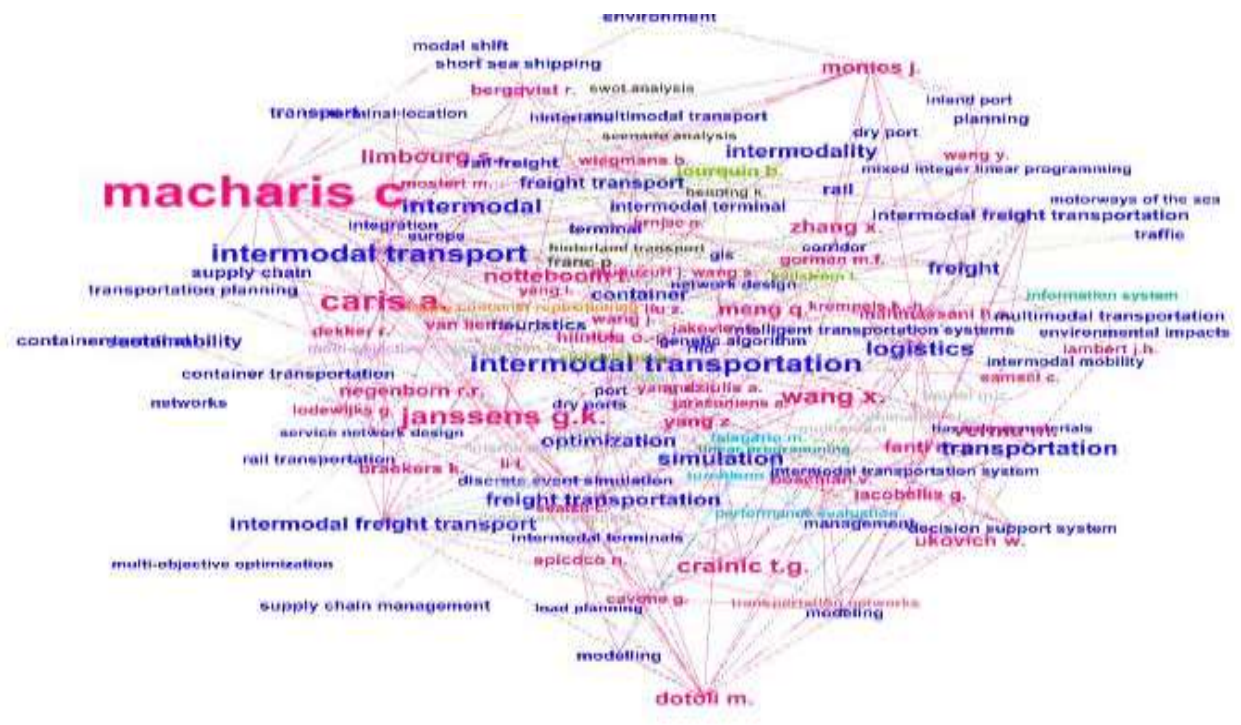

Fig. 6. Network diagram using authors and keywords coappearing in the same papers 
Fig. 7 shows association between authors and source titles, coappearing in the same papers with the following configuration: Nodes: 374 Edges: 672; Filtering Mode: Remove nodes < 3 links; Disconnected nodes removed: 3476
Further, it is filtered manually setting degree filter to 635. It builds a network diagram shown in Fig. 7 with 54 nodesand 96 edges.

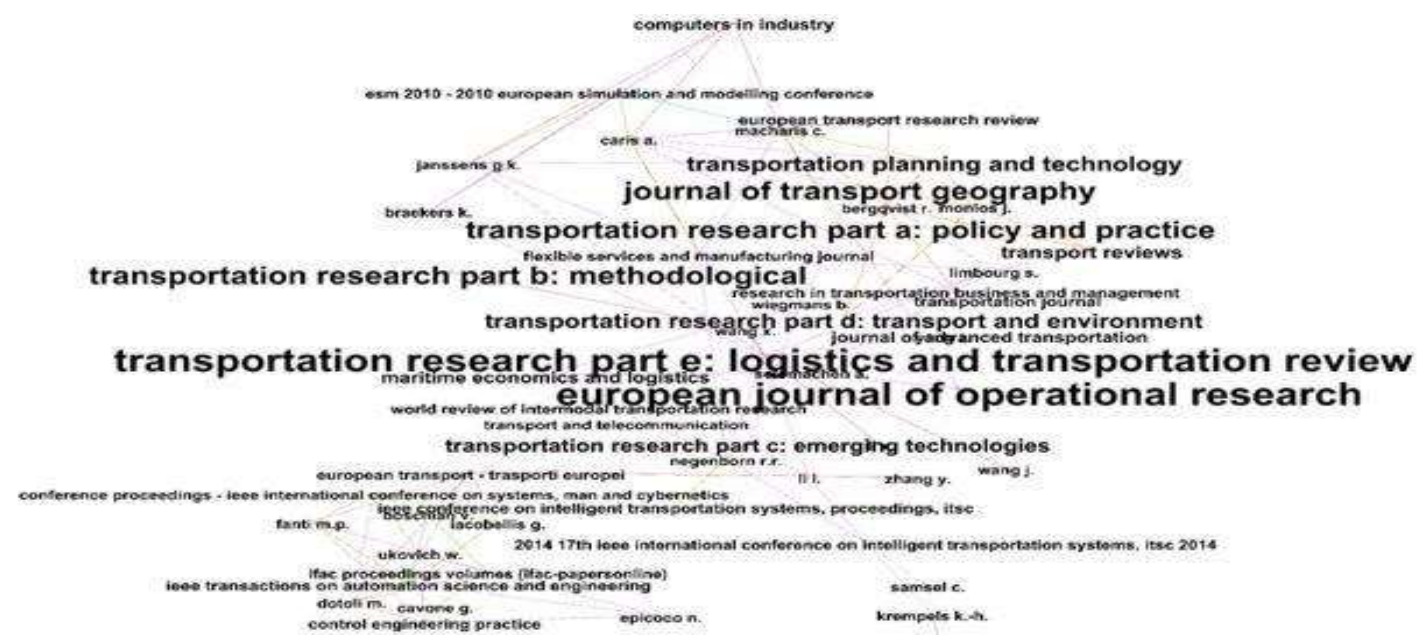

Fig. 7. Network diagram using authors and source titles coappearing in the same papers

In Fig. 7, comparatively big size of the fonts of source titles based on citations received by the publications 'transportation research part e: logistics and transportation review', 'european journal of operational research' and 'journal of transport geography' indicates topmost journals in intermodal transportation. However, despite having maximum number of publications but less citations source title 'transportation research record' could not be seen prominently in the network diagram.
Fig. 8, 9, 10, $11 \& 12$ are partially picked up from original network diagram generated using networks of authors linked by co-publication in intermodal transportation with the following configuration:

Nodes: 1333 Edges: 3013; Filtering Mode: Remove nodes < 3 links; Disconnected nodes removed: 1853

The size of the fonts in these diagrams indicates the most prominent author linked in that network of co-author

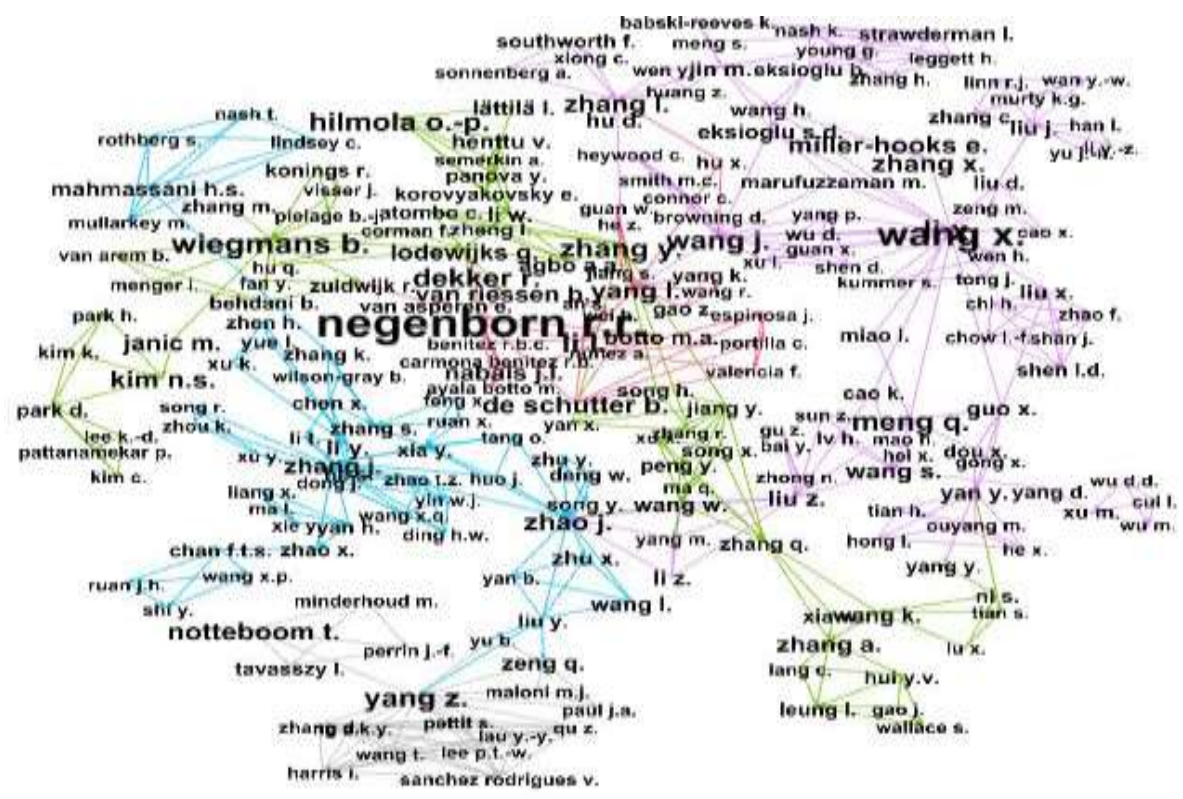

Fig. 8. Network diagram using authors linked by co-publication 


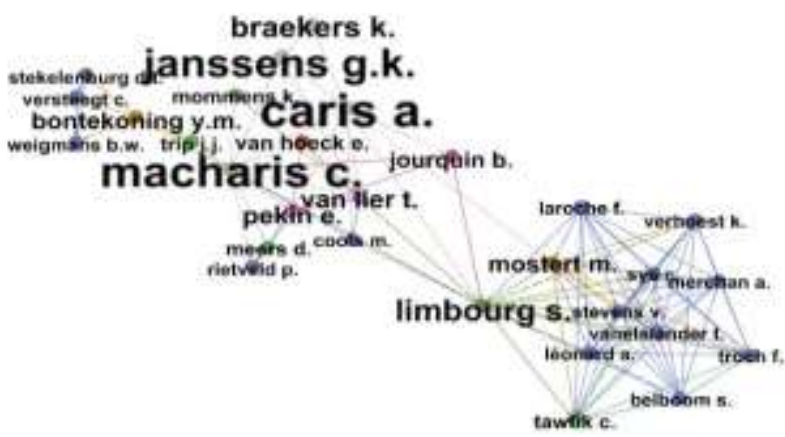

Fig. 9 Network diagram using authors linked by co-publication

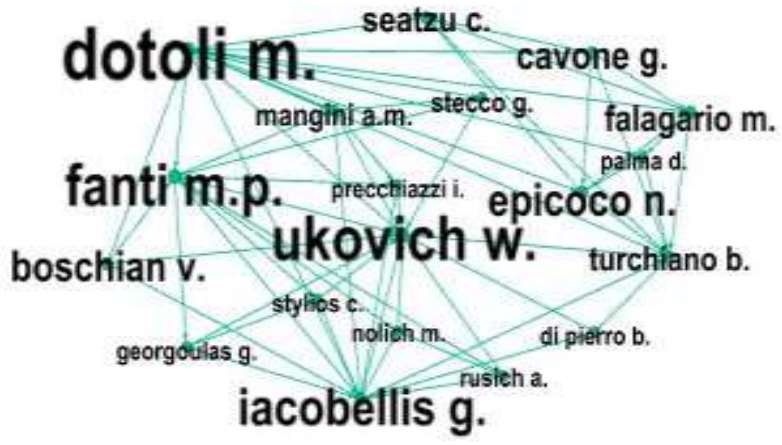

Fig. 10 Network diagram using authors linked by co-publication

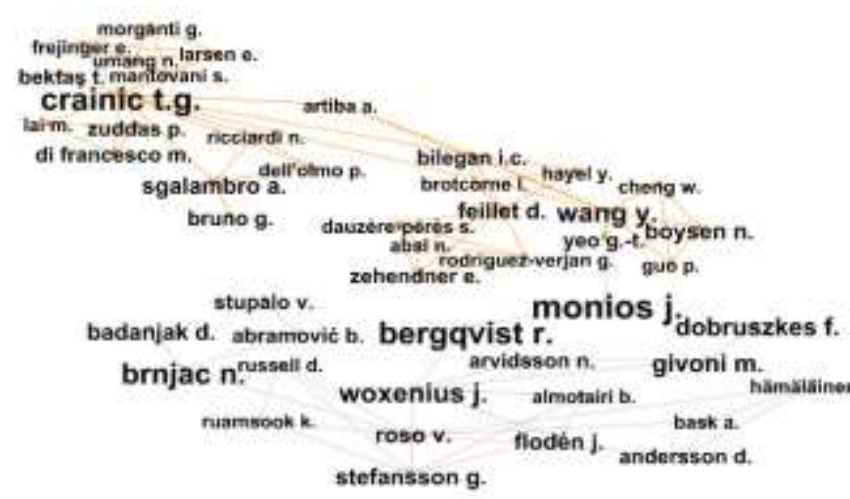

Fig. 11. Network diagram using authors linked by co-publication

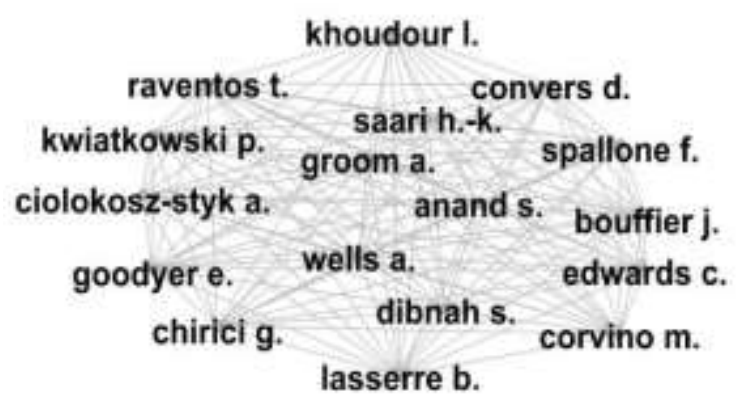

Fig. 12 Network diagram using authors linked by co-publication
'The issue. traffic, health, environment; intelligent solutions sustaining urban economies' has been co-authored by 17 authors 'Bouffier J., Wells A., Dibnah S., Ciolokosz-Styk A., Spallone F., Khoudour L., Goodyer E., Edwards C., Anand S., Convers D., Chirici G., Lasserre B., Raventos T., Kwiatkowski P., Saari H.-K., Groom A., Corvino M.’ which have been reflected in Fig. 12 as a single network.

\section{LITERATURE REVIEW}

Top cited publications along with few other intermodal transportation publications had reviewed in this section.

Simulation of intermodal transport risks and costs have been studied by Lorenc and Kuźnar (2017) considering three different variants through the supply chain. This help to identify risk and take appropriate action to reduce cost[6].

Roso et.al., (2015) studied types of services for three seaport-inland port dyads in three different continents. Understanding of four standard services such as rail drayage transport, transhipment, storage, customs clearance and thirteen value added services such as cleaning, repair, inspection, quarantine, stripping and stuffing, empty container depots, reefer plugs, cross-docking, quality and inventory control, pre-assembly, packing/unpacking/repacking, freight forwarding, and nondrayage container haulage could be used as benchmark for inland ports for devising business portfolio[7].

Steadieseifi et al., (2014) considered tactical, strategic and operational level issues and concluded that integrating different levels of planning might provide more reliability, flexibility, and more important sustainability, generating more efficient solutions for multimodal transportation planning[8].

Metro cities need integrated transport systems consisting of different modes including bus, suburban trains, bicycles considering demand and topography of the area. These might help to improve travel time ratio, travel cost ratio and service ratio. Intermodal transfer facility plays a vital role in intermodal transportation. In metro cities public transport system should be integrated with many other systems such as park and ride facilities, integrated fare and ticketing strategies, quality interchange system and passenger information system. It is necessary that all integrated systems should complement not compete (Shrivastava and O’Mahony, 2010)[9].

Intermodal planning approach has been studied by Goetz et.al., (2007) for seven states by the department of transportation (DOT) in the United States in two different regions. DOT's are becoming intermodal agencies for planning intermodal transports system efficiently and effectively. However, highway planning's has been dominant over intermodal approaches[10].

Merrina et al., (2006) discussed random networks and inhomogeneous networks[11].

Role of rail transport in intermodal transportation had been studied by Racunica and Wynter (2005) using hub 
and spoke model[12]. The study conducted on 32 terminals in the Alpine region for three cost scenarios. Empirical sensitivity analysis shows that the model appears to be quite sensitive to scale economies

Intermodal transportation is a necessity for moving human or cargoes using different transportation modes. It's an emerging field of operation research which can be explored using different network models (Macharis and Bontekoning, 2004)[13].

Bontekoning et al., (2004) reviewed 92 publications to identify the characteristics of the intermodal research community and scientific knowledge base. They have examined studies related to drayage, rail haul, transhipment, standardisation, multi-actor chain management and control, mode choice and pricing strategies, intermodal transportation policy and planning and all other remailing categories[14].

Arnold et al., (2004) used a linear programming approach for locating rail-road terminals for freight transport. The model had been applied to the Iberian Peninsula using five scenarios considering variations in the supply of transport. They concluded that variation of the relative cost of rail has an impact on location. However, relocation of new terminals within Spain or Portugal will not significantly increase the market share[15].

Choong et al., (2004) studied empty containers movement for potential container-on-barge activities in the Mississippi River basin using integer programming and concluded that a longer planning horizon helps in better empty container distribution[16].

Janic (2003) developed a model to determine the internal and external costs of intermodal and road freight transport networks. He investigated the effects of European Union policy on the prospective competition between two networks from a social perspective[17].

Problems related to storage yards of terminals such as quality control, yard cranes, storage space and IT studied by Zhang et al., (2003). They proposed a rolling horizon approach to reduce workload imbalance in the yard using mathematical programming model in two levels[18].

It's easy to anticipate and understand the need for investments in intermodal transportation using the geography of freight transportation networks. GIS mapping was used to construct and process shipment routes considering different combinations of truck, rail and water transportation. Mapping allows the different mode to be linked together via more than one transportation terminals (Southworth \& Peterson, 2000)[19].

Hayut (1981) demonstrated the dynamic development process of a container port system as a five-phase model. He used North American container port as a case study containing implications of containerization to ship operators, ports, and the inland distribution system[20].

\section{FUTURE SCOPE OF THE STUDY \& RESULTS}

Designing highly responsive and highly efficient supply chain has become extremely important in freight transport. No doubt, today's logistics operations intermodal transportation observes many benefits over unimodal transportation. Many other aspects in association with intermodal transportation could be extended using the bibliometrics presented herewith to achieve efficiency and effectiveness in the supply chain.

\section{LIMITATIONS, IF ANY}

Data used in this research is retrieved using the Scopus database only. Though most of the transportation-based journals indexed in the Scopus database, there might be some researches missed out. The citation data used herewith is the Scopus database only, which might differ from other databases. Though, enough care has been taken to check downloaded data sheets, error if any may lead to different interconnectedness in a network diagram. Many other combinations of networks would possible using different input criteria's, but only a few considered in this research paper.

\section{CONCLUSION}

Intermodal transportation is a need of the hour in every emerging field. Intermodal transportation research is happening across the world.

Though intermodal transportation developments and research is happening across the world, researchers from the US and Europe have taken lead in publishing researches in intermodal transportation.

The keyword 'intermodal transportation' used for retrieval of the database from Scopus is a popular keyword among the intermodal transportation research fraternity. The subject area for these researches mostly classified under 'engineering' and 'social sciences' category. Since 1985 almost all transportation and operations research journals have been considering intermodal transportation studies for inclusion, however, increased trends have been observed form 2005 till date. Citation analysis reveals that researches published in transportation and operations research journals have been referred by almost all researchers in intermodal transportation. In this paper, network diagram portrays the interconnectedness among authors, citations, co-authors linkage and leading journals in the area of intermodal transportation. This Scopus database based comprehensive research in terms of bibliometrics will lay the foundation for the researchers looking forward to learning popular and significant researches in intermodal transportation for further research.

\section{REFERENCES}

1. https://www.itf-oecd.org/sites/default/files/docs/keytransport-statistics-2018.pdf (accessed on 22 Dec 2018)

2. Pritchard, A. (1969). Statistical bibliography or bibliometrics. Journal of documentation, 25(4), 348-349.

3. Ding, Y., \& Cronin, B. (2011). Popular and/or prestigious? Measures of scholarly esteem. Information Processing \& Management, 47(1), 80-96.

4. Bornmann, L., \& Daniel, H. D. (2008). What do citation counts measure? A review of studies on citing behavior. Journal of documentation, 64(1), 45-80.

5. Hong Yeoh, K., \& Kaur, K. (2008). Subject support in collection development: Using the bibliometric tool. Collection Building, 27(4), 157-166. 
6. Lorenc, A., \& Kuźnar, M. (2017). The impact of cargo monitoring systems usage on intermodal transport risk and costs. World Review of Intermodal Transportation Research, 6(4), 336-351.

7. Roso, V., Russell, D., Ruamsook, K., \& Stefansson, G. (2015). Seaport-inland port dyad dynamics: an investigation of service provisions and intermodal transportation linkages. World Review of Intermodal Transportation Research, 5(3), 263-280.

8. SteadieSeifi, M., Dellaert, N. P., Nuijten, W., Van Woensel, T., \& Raoufi, R. (2014). Multimodal freight transportation planning: A literature review. European journal of operational research, 233(1), 1-15.

9. Shrivastava, P., \& O’Mahony, M. (2010). Integrated approach towards sustainable development. Oceania, 12(1.1), 13-4.

10. Goetz, A. R., Szyliowicz, J. S., Vowles, T. M., \& Taylor, G. S. (2007). Assessing intermodal transportation planning at state departments of transportation. World Review of Intermodal Transportation Research, 1(2), 119-145.

11. Merrina, A., Sparavigna, A., \& Wolf, R. A. (2006). The intermodal networks: a survey on intermodalism. arXiv preprint physics/0609085.

12. Racunica, I., \& Wynter, L. (2005). Optimal location of intermodal freight hubs. Transportation Research Part B: Methodological, 39(5), 453-477.

13. Macharis, C., \& Bontekoning, Y. M. (2004). Opportunities for OR in intermodal freight transport research: A review. European Journal of operational research, 153(2), 400-416.

14. Bontekoning, Y. M., Macharis, C., \& Trip, J. J. (2004). Is a new applied transportation research field emerging?A review of intermodal rail-truck freight transport literature. Transportation Research Part A: Policy and Practice, 38(1), 1-34.

15. Arnold, P., Peeters, D., \& Thomas, I. (2004). Modelling a rail/road intermodal transportation system. Transportation Research Part E: Logistics and Transportation Review, 40(3), 255-270.

16. Choong, S. T., Cole, M. H., \& Kutanoglu, E. (2002) Empty container management for intermodal transportation networks. Transportation Research Part E: Logistics and Transportation Review, 38(6), 423-438.

17. Janic, M. (2007). Modelling the full costs of an intermodal and road freight transport network. Transportation Research Part D: Transport and Environment, 12(1), 33-44.

18. Zhang, C., Liu, J., Wan, Y. W., Murty, K. G., \& Linn, R. J. (2003). Storage space allocation in container terminals. Transportation Research Part B: Methodological, 37(10), 883-903.

19. Southworth, F., \& Peterson, B. E. (2000). Intermodal and international freight network modeling. Transportation Research Part C: Emerging Technologies, 8(1-6), 147166.

20. Hayut, Y. (1981). Containerization and the load center concept. Economic geography, 57(2), 160-176

\section{AUTHORS PROFILE}

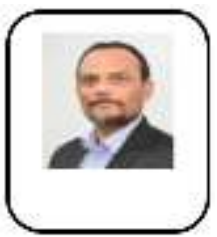

Sanjeev Kadam is an academician in the field of operations management with a mechanical engineering background. Presently he is associated with Amity University Mumbai as an Assistant Professor. He carries versatile military experience in mechanical engineering operations and maintenance field. Also, he had experience in manpower consultancy for oil,

gas, petrochemical, power and manufacturing sectors. His scholarly areas of interest include - operations management and operations research, logistics and supply chain management, business research methods, quality management and project management. He is currently pursuing his $\mathrm{PhD}$ research work from Symbiosis International (Deemed University), Pune, India.

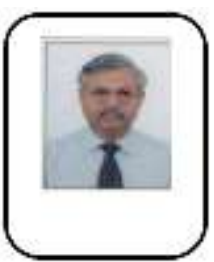

Prabir Kumar Bandyopadhyay is a Professor at the Symbiosis Institute of Business Management, Symbiosis International (Deemed University), Pune, India. He has a $\mathrm{PhD}$ in engineering and had a long stint in management consultancy and training with National Productivity Council, India. He worked with ISPAT Group and Hindustan National Glass looking after

various initiatives like TPM, Six Sigma, enterprise risk management and business excellence. He is a Six Sigma black belt and qualified business excellence assessor. 